\title{
Penentuan Kadar Flavonoid Ekstrak Etil Asetat Daun Sukun (Artocarpus altilis)
}

\section{Determination of Flavonoid Content of Ethyl Acetate Extract of Breadfruit Leaves (Artocarpus altilis)}

\author{
A.Trihadi Kusuma, Andi Adelah, Zainal Abidin, Ahmad Najib \\ Universitas Muslim Indonesia, Jl. Urip Sumoharjo No.KM. 5, Panaikang, Panakkukang, Kota Makassar, \\ Sulawesi Selatan 90231 \\ Kontak : andi.trihadi84@gmail.com
}

\begin{abstract}
Abstrak
Daun sukun (Artocarpus altilis) merupakan salah satu obat tradisional yang sudah lama digunakan untuk mengatasi berbagai penyakit. Beberapa senyawa yang telah diketahui mampu mengambat pertumbuhan kanker yang terdapat dalam daun sukun adalah senyawa golongan flavonoid. Penelitian ini bertujuan untuk menentukan kadar flavonoid ekstrak etil asetat daun sukun. Sampel diekstrak menggunakan metode maserasi dengan pelarut etil asetat. Penentuan kadar flavonoid menggunakan spektrofotometri yang diukur pada panjang gelombang $435 \mathrm{~nm}$, dengan pembanding kuersetin (QE). Hasil penelitian ini menunjukkan kandungan flavonoid pada ekstrak etil asetat daun sukun adalah 29,442 $\pm 1,20 \mathrm{mgQE} / \mathrm{g}$.
\end{abstract}

Kata Kunci : Daun Sukun (Artocarpus altilis), flavonoid, kuersetin, spektrofotometer UV-Vis

\begin{abstract}
Breadfruit leaf (Artocarpus altilis) is one of some traditional medicine had been used for treatment of various diseases. Some compounds that have been knows as cancer agent in breadfruit leaf are flavonoids. This study aimed to determine the flavonoid content of ethyl acetate extract of breadfruit leaves. The sample were extracted by maceration method using ethyl acetate. Determination of flavonoid content use spectrophotometry methods at the maximum wavelength $435 \mathrm{~nm}$ with quercetin as standard $(Q E)$. The result showed content flavonoid in ethyl acetate extract of the breadfruit leaves were 29,442 $11,20 \mathrm{mgQE} / \mathrm{g}$.
\end{abstract}

Keywords : Breadfruit leaves (Artocarpus altilis), flavonoid, quercetin, UV-Vis spectrophotometer

\section{PENDAHULUAN}

Tumbuhan yang berkhasiat sebagai obat memiliki zat - zat penting yang sangat berperan dalam menentukan aktivitas kerja tumbuhan obat tersebut, salah satunya yaitu senyawa golongan flavonoid. Zat ini salah satunya berpotensi sebagai antioksidan (Selawa, Runtuwene, \& Citraningtyas, 2013). Senyawa-senyawa golongan flavonoid mempunyai berbagai fungsi penting untuk kesehatan, antara lain dalam menurunkan risiko serangan penyakit kardiovaskular, tekanan darah, aterosklerosis, dan sebagai antioksidan (Hodgson \& Kevin, 2006).

Flavonoid merupakan golongan terbesar senyawa fenol alam (Harborne, 1987). Flavonoid merupakan senyawa yang ditemukan pada buah-buahan, sayur-sayuran, dan beberapa minuman yang memiliki beragam manfaat biokimia dan efek antioksidan (Cristobal \& Donald, 2000). Oleh karena itu makanan yang kaya flavonoid dianggap penting untuk mengobati penyakit penyakit, seperti kanker dan penyakit jantung 
(yang dapat memburuk akibat oksidasi lipoprotein densitas-rendah) (Heinrich, Petko, Maria, Anton, \& Antonin, 2009).

Manfaat flavonoid yang telah diketahui, antara lain untuk melindungi struktur sel, meningkatkan efektifitas vitamin C, antiinflamasi, mencegah keropos tulang dan sebagai antibiotik (Lumbessy, Abidjulu, \& Paendong, 2013). Selain itu flavonoid mempunyai efek antihipertensi, dan isoflavon tertentu merangsang pembentukan estrogen dan insektisidal (Nugrahaningtyas, Matsjeh, \& Wahyuni, 2005).

Beberapa tanaman obat Indonesia mengandung senyawa flavonoid, salah satunya yaitu tanaman sukun, yang secara empiris digunakan sebagai obat penyakit pembesaran limpa dan sebagai obat luar pada penyakit kulit (Heyne, 1987). Selain itu beberapa senyawa isolat dari daun sukun (Artocarpus altilis) mempunyai aktivitas biologi diantaranya antiplatelet, antifungi, antibakteri, penghambatan sel leukemia, antitumor, antioksidan, ACE inhibitor, antidiabetes, anthehelmintik, protease inhibitor, immunomodulator, antiinflamasi, penghambat biosintesis melanin, dan sebagai agen kosmetik (Handa, Khanuja, Longo, \& Rakesh, 2008).

Kadar flavonoid hasil ekstraksi tergantung dari penyari yang digunakan. Salah satu penyari yang dapat menyari senyawa flavonoid dalam konsentrasi yang besar adalah etil asetat (Stankovic, 2011). Konsentrasi flavonoid pada daun sukun sangat mempengaruhi aktivitas yang nantinya dihasilkan. Penelitian ini bertujuan menentukan kadar flavonoid dalam daun sukun, khususnya pada ekstrak etil asetat daun sukun. Hasil penelitian ini dapat menjadi acuan dalam memanfaatkan daun sukun sebagai bahan aktif dalam membuat ekstrak yang digunakan sebagai antioksidan atau antiinflamasi.

\section{METODE PENELITIAN}

\section{Bahan dan alat}

Bahan-bahan yang digunakan seperti etil

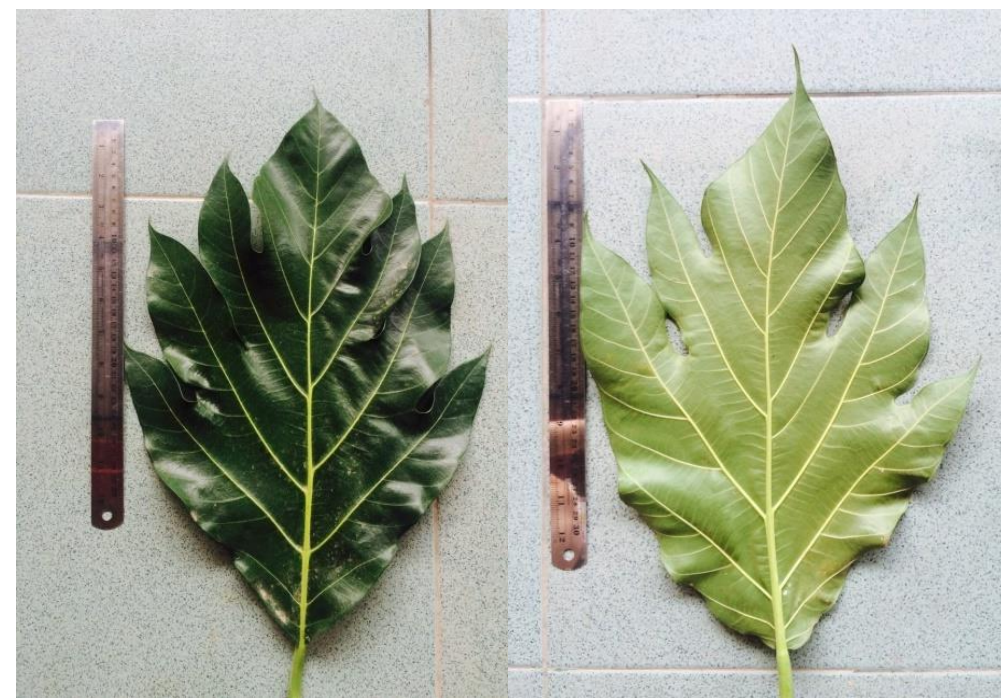

Gambar 1. Tampak atas (kiri) dan bawah daun sukun (kanan) 
asetat, etanol $96 \%$, aluminium klorida, kalium asetat, dan kuersetin (Merck). Alat analisis kadar mengunakan Spektrofotometer UV-Vis (Apel PD-303UV)

\section{Penyiapan Sampel dan Ekstraksi Sampel}

Daun sukun yang digunakan sebagai sampel, diambil dari Kabupaten Sidrap. Sampel dideterminasi di Laboratorium Farmakognosi-Fitokimia Fakultas Farmasi Universitas Muslim Indonesia. Sampel daun sukun yang diambil selanjutnya dibuat menjadi simplisia dengan cara dikeringkan tidak dibawah matahari langsung, kemudian diserbuk untuk kemudian siap untuk diekstraksi. Serbuk simplisia selanjutnya diekstraksi dengan metode maserasi menggunakan penyari etil asetat, dengan cara perendaman. Sampel kemudian disaring tiap 24 jam, ampas rendam kembali dengan cairan penyari yang baru. Proses ekstraksi ini dilakukan sebanyak 3 kali replikasi untuk mendapatkan rendemen ekstrak yang besar. Hasil ekstraksi ini kemudian dikeringkan hingga diperoleh ekstrak kering.

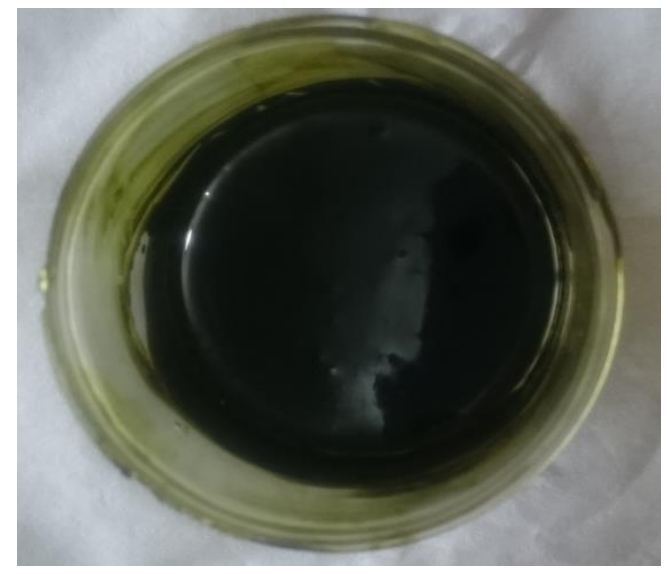

Gambar 2. Ekstrak etil asetat daun sukun

\section{Penentuan Panjang Gelombang} Maksimum dan Pembuatan Kurva Baku

Larutan standar kuersetin dibuat dengan berbagai konsentrasi yaitu 6, 8, 10, 12, 14 ppm. Absorban larutan kuersetin 6 ppm diukur pada range panjang gelombang $400-450 \mathrm{~nm}$, di mana absorban yang paling besar menunjukkan panjang gelombang maksimum. Masing-masing konsentrasi larutan kuersetin tersebut diukur absorbannya pada panjang gelombang maksimum, selanjutnya hasil absorban yang diperoleh dibuat kurva baku guna menghitung kadar flavonoid sampel dengan menggunakan persamaan garis lurusnya. Perlakuan dalam prosedur ini harus sesuai dengan perlakuan yang dilakukan pada prosedur penentuan kadar flavonoid.

\section{Penentuan Kadar Flavonoid}

Ekstrak etil asetat daun sukun dibuat larutan dengan konsentrasi 300 ppm dalam etanol 96\%. Larutan ini sebanyak $1 \mathrm{~mL}$ ditambahkan dengan $1 \mathrm{~mL}$ Aluminium klorida $2 \%$ dan $1 \mathrm{~mL}$ kalium asetat $120 \mathrm{mM}$. Campuran larutan ini didiamkan selama 1 jam pada suhu kamar. Setelah itu campuran larutan diukur pada panjang gelombang 435 $\mathrm{nm}$ menggunakan spektroforometer UV-Vis, proses ini dilakukan sebanyak 3 replikasi. Penentuan kadar flavonoid ini menggunakan larutan kuersetin sebagai standar dan dilakukan juga pengukuran absorban kontrol 
Tabel 1. Hasil Ekstrak Etil Asetat Daun Sukun (Artocarpus altilis)

Berat Simplisia Berat Ekstrak (gram) \% Rendamen Rata-rata \% Rendamen
(gram)

\begin{tabular}{|c|c|c|c|}
\hline 50,003 & 5,2643 & 10,528 & $10,471 \pm 0,19$ \\
\hline 50,002 & 5,1312 & 10,262 & \\
\hline 50,000 & 5,3126 & 10,625 & \\
\hline
\end{tabular}

sampel. Kadar flavonoid yang diperoleh dalam satuan mgQE/gram ekstrak, artinya tiap gram ekstrak mengandung sebanyak milligram flavonoid yang ekuivalen dengan kuesetin (Stankovic, 2011).

\section{HASIL DAN PEMBAHASAN}

Penelitian ini menggunakan metode ekstraksi untuk memisahkan komponen kimia senyawa yang terkandung dalam daun sukun. Metode ekstraksi yang digunakan yaitu metode maserasi dengan menggunakan pelarut etil asetat. Alasan menggunakan pelarut etil asetat sebab dapat melarutkan senyawa-senyawa seperti beberapa alkaloid, flavonoid, monoglikosida, glikosida (Syahri, 2016). Pemilihan metode maserasi sebab

Tabel 2. Hasil pengukuran panjang gelombang maksimal ( $\chi$ maks) kuersetin

\begin{tabular}{cc}
\hline $\begin{array}{c}\text { Panjang } \\
\text { gelombang } \\
\mathrm{nm}\end{array}$ & Absorban \\
\hline 400 & 0,173 \\
\hline 405 & 0,192 \\
\hline 410 & 0,215 \\
\hline 415 & 0,237 \\
\hline 420 & 0,254 \\
\hline 425 & 0,267 \\
\hline 430 & 0,276 \\
\hline 435 & 0,278 \\
\hline 440 & 0,270 \\
\hline 445 & 0,253 \\
\hline 450 & 0,230 \\
\hline
\end{tabular}

lebih sederhana, mudah dan tanpa pemanasan. Proses maserasi dilakukan secara berulang untuk mendapatkan hasil ekstrak yang maksimal. Perhitungan rendemen ekstrak yang diperoleh dari 50 gram simplisia daun sukun yang diekstraksi, dapat dilihat pada tabel 1.

Beberapa senyawa turunan fenilpropanoid seperti flavonoid dan flavones terkandung dalam tanaman sukun. Lebih dari 70 jenis senyawa turunan dari jalur fenilpropanoid yang terkandung dalam tanaman sukun, yang telah teridentifikasi, di mana beberapa senyawa tersebut telah diisolasi dan telah menunjukkan aktivitas biologis, seperti penghambatan agregat platelet, antibakteri, antifungi, dan antitumor (Sikarwar, Hui, Subramaniam, Valeisamy, Yean, \& Balaji, 2014). Aktivitas biologis yang dihasilkan tersebut berhubungan dengan adanya kandungan senyawa turunan dari jalur fenilpropanoid, seperti flavonoid, sehingga

Tabel 3. Hasil pengukuran absorban larutan standar kuarsetin pada panjang gelombang maksimum $435 \mathrm{~nm}$.

\begin{tabular}{cc}
\hline Konsentrasi (ppm) & Absorbansi $(\mathrm{y})$ \\
\hline 6 & 0,278 \\
8 & 0,378 \\
10 & 0,442 \\
12 & 0,555 \\
14 & 0,628 \\
\hline
\end{tabular}


perlu dilakukan penelitian untuk menentukan kadar kandungan flavonoid dari daun sukun, yang bisa jadi acuan dalam pemberian pengobatan menggunakan ekstrak etil asetat daun suku.

Penentuan kadar flavonoid yang dilakukan pada penelitiian ini menggunakan senyawa Kuersetin sebagai larutan standar. Kuersetin merupakan golongan flavonoid yang sering ditemukan dalam tumbuhan dan diketahui memiliki banyak aktivitas biologis, seperti sebagai antioksidan. Pengukuran absorban untuk penentuan panjang gelombang maksimum dilakukan pada range panjang gelombang 400 - 450 nm. Hasil yang diperoleh menunjukkan bahwa panjang gelombang maksimum larutan standar kuersetin berada pada panjang gelombang $435 \mathrm{~nm}$ (tabel 2). Hasil pengukuran absorban larutan standar kuersetin (tabel 3) dibuat menjadi kurva baku yang dapat dilihat pada gambar 3 .

Analisis flavonoid dilakukan dengan menggunakan Spektrofotometri UV-Vis karena flavonoid mengandung sistem aromatis yang terkonjugasi dan dapat

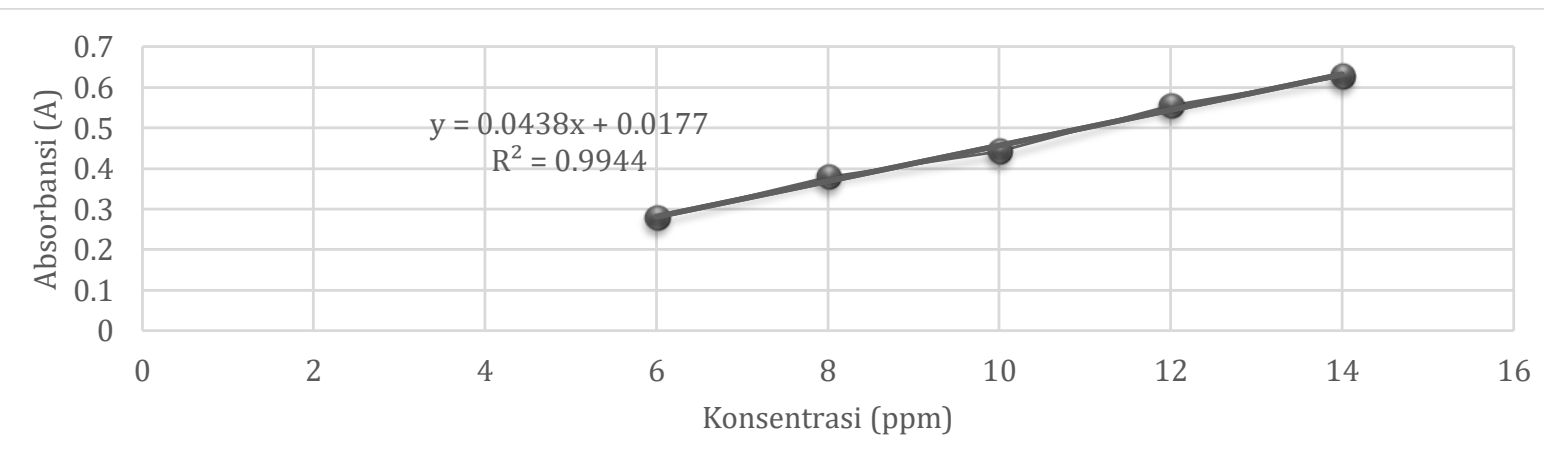

Gambar 3. Kurva baku kuersetin

Tabel 4. Hasil perhitungan absorban sampel

\begin{tabular}{cccc}
\hline Replikasi & Absorban Sampel & $\begin{array}{c}\text { Absorban } \\
\text { Kontrol Sampel }\end{array}$ & $\begin{array}{c}\text { Absorban } \\
\text { Sampel Sesungguhnya }\end{array}$ \\
\hline 1 & 0,422 & 0,167 & 0,255 \\
2 & 0,441 & 0,167 & 0,274 \\
3 & 0,456 & 0,167 & 0,289
\end{tabular}

Tabel 5. Hasil Penetapan Kadar Flavonoid Total \% (b/b) pada ekstrak etil asetat daun sukun.

\begin{tabular}{ccccc}
\hline Replikasi & $\begin{array}{c}\text { Absorban } \\
\text { ekstrak } \\
\text { sesungguhnya } \\
(\mathrm{y})\end{array}$ & $\begin{array}{c}\text { Kandungan } \\
\text { Flavonoid Total } \\
\text { Awal (mg/L) }\end{array}$ & $\begin{array}{c}\text { Kandungan } \\
\text { Flavonoid Total } \\
\text { (mgQE/g } \\
\text { ekstrak) }\end{array}$ & $\begin{array}{c}\text { Rata-rata Kandungan } \\
\text { Flavonoid Total } \\
\text { (mgQE/g ekstrak) }\end{array}$ \\
\hline 1 & 0,255 & 9,2305 & 28,054 & $29,442 \pm 1,20$ \\
2 & 0,274 & 9,6643 & 30,135 & \\
\cline { 2 - 4 } 3 & 0,289 & 10,006 & 30,137 & \\
\hline * Kandungan flavonoid awal adalah kadar flavonoid dalam mg/L yang terkandung dalam larutan ekstrak \\
daun sukun yang dibuat sesuai dengan prosedur penentuan kadar flavonoid \\
* Kandungan flavonoid total adalah kadar flavonoid yang terkandung dalam 1 gram ekstrak dengan satuan \\
mgQE/1 gram
\end{tabular}




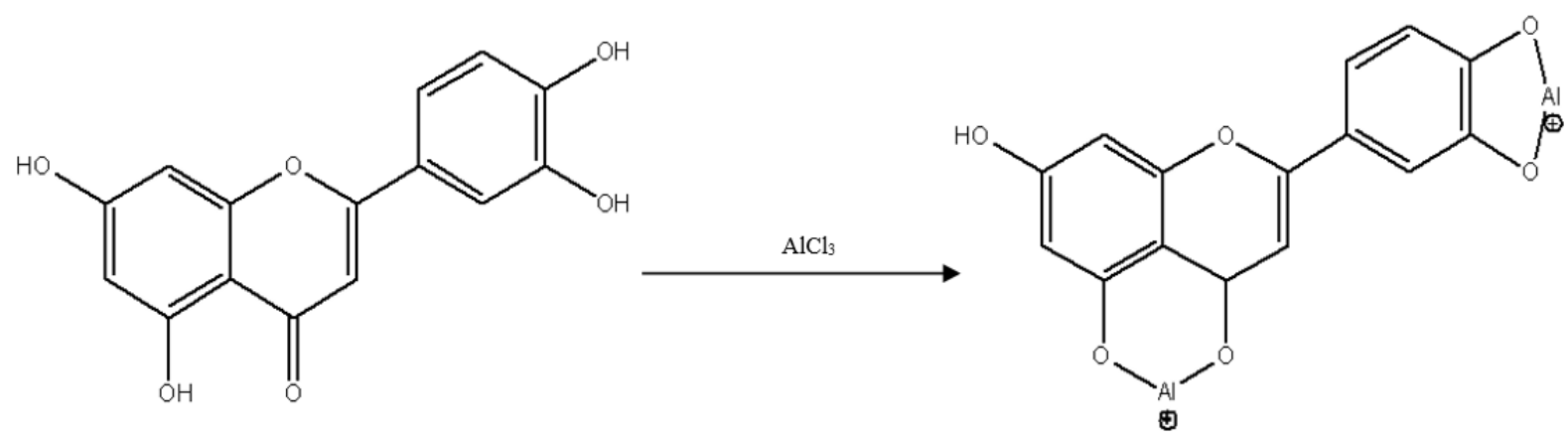

Gambar 4. Reaksi kompleks aluminium-flavonoid (Sepahpour, Selamat, Manap, \& Razis, 2018)

menunjukkan pita serapan kuat pada daerah UV-Vis (Rohyami, 2008). Namun secara umum, penentuan kadar total flavonoid pada suatu sampel tanaman didasarkan atas pembentukan senyawa kompleks aluminium (Al-Flavonoid), berupa larutan berwarna kuning. Penambahan garam asetat pada penentuan kadar flavonoid dimaksudkan untuk menghasilkan pergeseran dan intensitas peak absorban yang lebih kuat (Pekal \& Pyrzynska, 2014). Senyawa kompleks khelat Al-Flavonoid terbentuk pada gugus keto dan gugus hidroksil dari flavonoid (Sepahpour, Selamat, Manap, \& Razis, 2018), reaksi yang terjadi dapat dilihat pada gambar 4 .

Absorban sampel sesungguhnya yang digunakan dalam perhitungan merupakan hasil pengurangan dari absorban sampel terhadap absorban kontrol sampel (tabel 4). Pengukuran absorban kontrol sampel dimaksudkan untuk menghilangkan pengaruh absorban dari warna larutan sampel yang dibuat. Hasil penelitian ini diperoleh kadar flavonoid total ekstrak etil asetat daun sukun sebesar 29,442 mgQE/g ekstrak, yang dapat dilihat pada tabel 5 .

\section{KESIMPULAN}

Hasil dari penelitian yang sudah dilakukan menunjukkan bahwa ekstrak etil asetat daun sukun mengandung senyawa flavonoid sebesar 29,442 $\pm 1,20 \mathrm{mgQE} /$ gram ekstrak.

\section{UCAPAN TERIMA KASIH}

Kami mengucapkan banyak terima kasih kepada Universitas Muslim Indonesia (UMI), terkhusus kepada Fakultas Farmasi dan Laboratorium Kimia Farmasi UMI, yang telah memfasilitasi kebutuhan sarana dan prasarana selama melakukan penelitian ini.

\section{DAFTAR PUSTAKA}

Cristobal, M., \& Donald, R. (2000). Akativitas Antiosidan Flavonoid. Oregon State university.

Handa, S., Khanuja, S., Longo, G., \& Rakesh, D. (2008). Extraction Technologies for Medicinal and Aromatic Plants. International Centre for Science and High Technology.

Harborne, J. (1987). Metode Fitokimia: Penuntun Cara Modern Menganalisa Tumbuhan,. (K. Padmawinata, \& I. Soediro, Trans.) Bandung: Institut Tehnologi Bandung (ITB).

Heinrich, M., Petko, D., Maria, K., Anton, S., \& Antonin, L. (2009). Farmakognosi dan Fitoterapi. (R. Winny, Syarif, \& dkk, Trans.) Jakarta: EGC. 
Heyne, K. (1987). Tanaman Berguna Indonesia II (2 ed.). Jakarta.

Hodgson, J., \& Kevin, D. (2006). Review Dietary Flavonoid:Efects on Endothelial Function and Blood Pressure. Journal of the Science of Food and Agriculture, 2492-2498.

Lumbessy, M., Abidjulu, J., \& Paendong, J. (2013). Uji Total Flavonoid pada Beberapa Tanaman Obat Tradisional di Desa Waitina Kecematan Mangoli Timur Kabupaten Kepuluan Sula Provinsi Maluku Utara. Jurnal Mipa UNSRAT ONLINE , 2 (1), 50-55.

Nugrahaningtyas, K., Matsjeh, S., \& Wahyuni, T. (2005). Isolasi dan Identifikasi Senyawa Flavonoid dalam Rimpang Temu Ireng (Curcuma aeruginosa). Jurnal Biofarmasi ISSN: 1693-2242, 3 (1), 32-38.

Pekal, A., \& Pyrzynska, K. (2014). Evaluation of Aluminium Complexation Reaction for FlavonoidContent Assay. Food Anal. Methods Vol. 7, DOI 10.1007/s12161-014-9814-x, 1776 - 1782.

Rohyami, Y. (2008). Penentuan kandungan Flavonoid dari Ekstrak Metanol Daging Buah mahkota Dewa (Phaleria macrocarpa Scheff Boerl). Jurnal Logika , 5 (1), 2-16.
Selawa, W., Runtuwene, M. R., \& Citraningtyas, G. (2013). Kandungan Flavonoid dan Kapasitas Antioksidan Total Ekstrak Etanol Daun Binahong (Anredera cordifolia). Jurnal Ilmiah Farmasi UNSTRAT, 18-22.

Sepahpour, S., Selamat, J., Manap, M. Y., \& Razis, A. F. (2018). Comparative Analysis of Chemical Composition,. Jounal Molecules Vol. 23 Ed 402, 2 - 17.

Sikarwar, M., Hui, B., Subramaniam, K., Valeisamy, B., Yean, L., \& Balaji, K. (2014). A Review on Artocarpus altilis (Parkinson) Fosberg (breadfruit). Journal of Applied Pharmaceutical Science Vol. 4 Ed. 08,091 - 097.

Stankovic, M. (2011). Total Phenolic Content, Flavonoid Concentration and Antioxidant Activity of Marrubium peregrinum L. Extract. Krajuevac Journal Science, 63-72.

Syahri, L. (2016). Pengaruh Fraksi Etil Asetat Ekstrak Etanol Buah Kemukus (Piper cubeba L.) Fructus Terhadap Memori Spasial Tikus jantan Galur Wistar Pasca Restraint Stress. Skripsi, Universitas Wahid Hasyim, Fakultas Farmasi, Semarang. 